Ann. rheum. Dis. (1962), 21, 59.

\title{
ERYTHEMA ANNULARE IN ADULTS WITH ACUTE RHEUMATISM
}

BY

\author{
J. S. KAMERMANN \\ Centre for Rheumatic Diseases, Amsterdam, Netherlands \\ (Medical Director: Dr. G. van Dam)
}

In the winter of 1959-1960 the number of patients with acute rheumatism who applied to our Centre for treatment was larger than in former years, and most cases presented with a forme fruste of the condition. The three cases reported differed from the others in that they presented with erythema annulare (EA). The chief outward sign of erythema annulare is a series of rings about $2 \mathrm{~mm}$. wide, with a diameter of $1-3 \mathrm{~cm}$., pale pink to bluish-red in colour. The rings may show a festoon-like confluence, and may usually be observed on the trunk, and less frequently on the extremities. The fact that they are not raised above the skin surface indicates that there is little exudation, and because itching and desquamation are absent they often pass unnoticed. Sometimes the rings become fully visible only when the skin is exposed to heat or cold. The erythema is susceptible to rapid changes in shape and colour and is also influenced by emotion (Wallgren, 1935).

Erythema annulare was described for the first time by Barlow (1883), who noted it in children with acute rheumatism, but as early as 1826 , Rayer had called attention to the association of acute rheumatism and skin affections (Perry, 1937). Lehndorff and Leiner (1922) and Lehndorff (1930) asserted that erythema annulare occurred only in acute rheumatism, and only when there also existed a rheumatic affection of the heart. In this way, the condition has acquired an unfavourable prognostic significance. It has been said never to occur in babies and only seldom in adults (Abt, 1935; Pellé and Massot, 1937; Ablard and Larcan, 1956a, b; Slater and Rosenbaum, 1959), but it has been observed in approximately 10 per cent. of children with acute rheumatism (Lehndorff and Leiner, 1930). Wallgren (1935), who analysed the incidence of erythema annulare in a group of 148 children with acute rheumatism (Table), concluded that erythema annulare occurred three to four times more often in cases with severe cardiac involvement.

TABLE

RESULTS IN 148 CHILDREN (WALLGREN, 1935)

\begin{tabular}{|c|c|}
\hline Cardiac Abnormality & Percentage with Erythema Annulare \\
\hline $\begin{array}{lll}\text { None } & \ldots & 33 \\
\text { Benign } & \ldots & 88 \\
\text { Malignant } & \ldots & 27\end{array}$ & $\begin{array}{r}9 \\
8 \\
30\end{array}$ \\
\hline
\end{tabular}

Traub (1937), studying a group of 166 children, came to the same conclusion. Consequently, when erythema appears, the possibility of cardiac involvement must be carefully investigated. The Table also shows that the prognosis is not bad in every case of erythema annulare and that in some the heart may remain wholly normal. Other authors have also given more favourable opinions concerning the prognosis in children and especially in adults (Gadrat, 1938; Ablard and Larcan, 1956a). This may be attributable to the decreased incidence of cardiac involvement in acute rheumatism since 1920 , which is due partly to improved living conditions and to the use of sulpha drugs and penicillin (Bland, 1960). Burke (1955) reported fourteen children with acute rheumatism and erythema annulare, in all of whom a cardiac abnormality was observed in the course of the disease; follow-up examinations for 3 to 42 months revealed that the heart was normal in six cases, whereas eight still showed abnormalities (murmurs and cardiac enlargement). This author regarded a still longer follow-up as necessary because the six patients with apparently normal hearts might develop abnormalities later on.

It is supposed that the erythema annulare, like the involvement of the cardiac valves, is due to an 
allergic reaction based on sensitization of the organism against streptococci. A higher degree of sensitization would manifest itself with more pronounced allergic reactions, and might lead, for example, to the appearance of Meynet's nodules (Wallgren, 1935; Traub, 1937). However, the intensity of the erythema is not necessarily parallel with the activity of the disease; it may be slight in severe cases (with high erythrocyte sedimentation rate; arthritis; fever; nodules, valvular affection) or severe in mild cases (Perry, 1937; Burke, 1955). The blood picture shows no eosinophilia (although Traub describes one case with 16 per cent. eosinophils. Intracutaneous injection of streptococcal protein leads to a skin reaction more often in patients with acute rheumatism than in other subjects (Coburn, 1931; Irvine-Jones, 1928; Swift, Wilson, and Todd, 1929). Typical erythema annulare only rarely appears around the injection site (Coburn, 1931 ; Winkler, 1947). Microscopical examination of the erythema annulare shows perivascular infiltrations of polynuclear cells in the upper layers of the skin (Carol and Krieken, 1935), and we observed the same appearance in our cases (Figure).

\section{Case Reports}

Case 1, a man aged 36 years, came to the Centre in February, 1960, complaining of a painful swelling of the knees which had been present for a week; he had previously been ill in bed for 2 weeks with fever and a painful throat.

Examination.-The tonsils were swollen. The heart was not enlarged, there were no murmurs, and the electrocardiogram was normal. The knees were swollen and hot and flexion was restricted. The upper arms and trunk presented a light pink, festoon-like nonpruritic erythema. The erythrocyte sedimentation rate was $25 \mathrm{~mm}$./hr. The antistreptolysin "O" test showed 800 units. The culture of the throat smear contained no Group-A haemolytic streptococci.

Diagnosis.-Acute rheumatism.

Treatment.-He was given salicylates, penicillin, and quartz-lamp irradiation, after which the articular lesions improved and the erythema disappeared. The administration of Penidural for prophylactic purposes provoked a slightly raised, mildly-itching, spotty erythema on the abdomen (no rings), which made it necessary to change to sulphadiazine therapy.

Result.-After 8 months the patient was in excellent condition and able to do heavy work. The erythrocyte

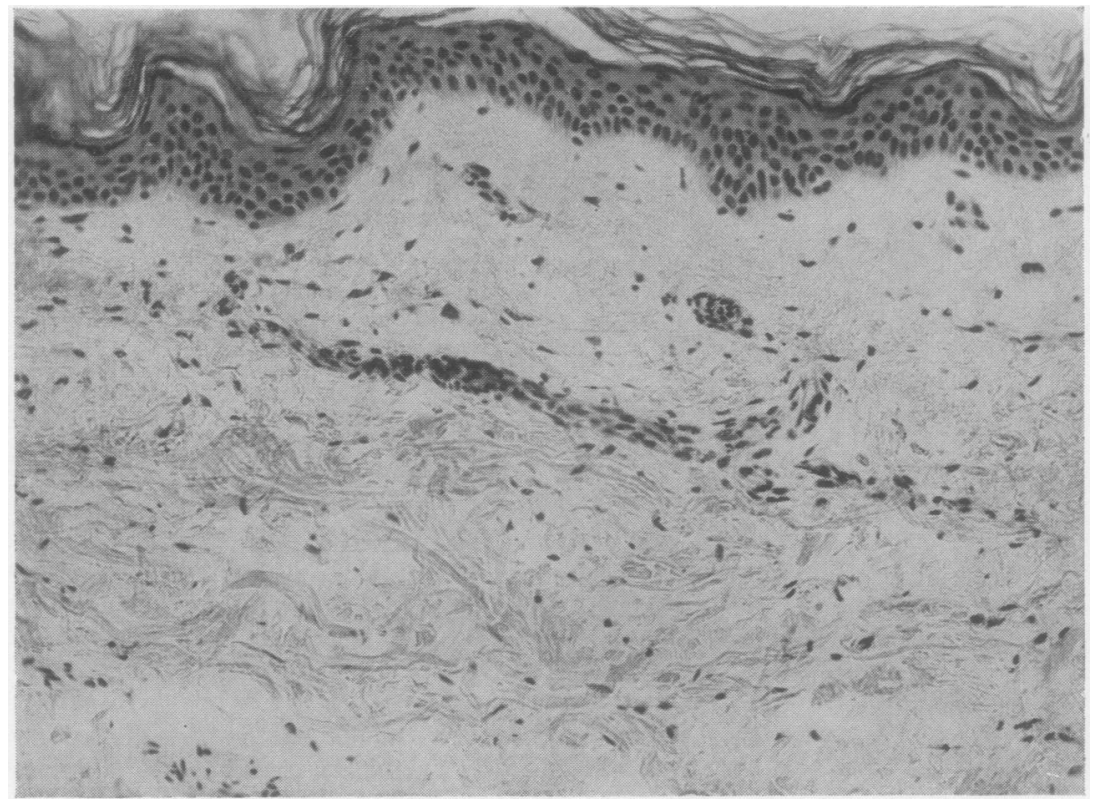

FIGURE.-Perivascular infiltrations of polynuclear cells in the upper layers of the skin. 
sedimentation rate was $4 \mathrm{~mm}$./hr, but the antistreptolysin " $O$ " titre remained high at 900 units. The heart and the electrocardiogram still showed no abnormalities.

Summary.-A man aged 36 had a first, mild attack of acute rheumatism with concomitant erythema annulare. He was given ambulant treatment. So far no cardiac abnormality has been demonstrated.

Case 2, a woman aged 26 years, complained in the autumn of 1959 of pain and swellings of the hands, hips, knees, and feet which had been present for 4 months. She had never suffered articular disturbances before, although she had had angina once every year.

Examination.-Only a few small finger joints were somewhat swollen, but most of the joints were painful on pressure and movement. A cardiac murmur could be heard (mitral stenosis). The erythrocyte sedimentation rate was $19 \mathrm{~mm}$. $/ \mathrm{hr}$.

Diagnosis.-Early rheumatoid arthritis was suspected.

Treatment.-Quartz-lamp irradiation.

Result.-By April there was only tenderness of the joints on pressure. The left shoulder, upper arm, and right thigh showed pale red erythematous rings, which did not itch or flake. The tonsils were slightly swollen. The antistreptolysin "O" test showed 500 units. The throat culture contained Group-A haemolytic streptococci.

The cardiac murmur could still be heard, and the patient was alleged to have retained a cardiac abnormality after an episode of diphtheria at the age of 9 , so that this may have been post-diphtherial myocarditis. There was a distinct mitral stenosis, and it could not be determined how long it had been present. It is possible that Group-A haemolytic streptococci may have been involved. The electrocardiogram was normal.

After treatment with salicylates and penicillin the erythema annulare disappeared. One of the later prophylactic Penidural injections was reported to have caused an erythema (no rings) all over the body, and sulphadiazine was used instead.

Summary.-A woman aged 26 who since her youth had had regular attacks of angina, without articular affection, and with a longstanding cardiac abnormality, experienced the first bout of subacute articular disturbances in the autumn of 1959. In the spring of 1960 , erythema annulare was observed, but there were no objective joint lesions.

Case 3, a woman aged 41 years, who had had several attacks of angina, was again affected in February, 1960, with a fever followed for the first time by joint lesions in the knees, ankles, wrists, elbows, and hands.
Examination.-The right knee and wrist were slightly swollen and there were nodules on both elbows. On the left thigh and right forearm there were slight, festoonshaped, pale red rings. The erythrocyte sedimentation rate was $40 \mathrm{~mm}$./hr. The antistreptolysin "O" test showed 3,200 units. The throat culture contained Group-A haemolytic streptococci.

Diagnosis.-The erythema annulare suggested acute rheumatism in spite of the subacute development. The heart and electrocardiogram showed no abnormalities.

Treatment.-Quartz-lamp irradiation, pyramidone, tonsillectomy, and prophylactic Penidural.

Result.-The antistreptolysin "O" titre fell to 800 units.

Summary.-A woman aged 41 years developed articular pains and erythema annulare after angina. The heart shows no abnormality.

\section{Discussion}

The first patient, an adult man, had a mild form of acute rheumatism associated with erythema annulare. So far he had not developed any cardiac abnormalities. In the second patient, in whom there were no objective abnormalities of the joints, the finding of erythema annulare immediately led to the correct interpretation of the articular discomfort and the cardiac abnormality. It is noteworthy that those patients who showed erythema annulare due to acute rheumatism also developed an erythema (of a different nature) which was due to the Penidural. Their skin was possibly hypersensitive to the circulating streptococcal antigens and certainly hypersensitive to the drug Penidural, and there may be a connexion between these two phenomena. The third patient had no cardiac abnormality, and developed no resistance to Penidural.

\section{Summary}

In an Out-patient Clinic for Rheumatic Diseases, out of 35 adult patients with acute rheumatism, three showed erythema annulare.

The uncertain appearance of the erythema annulare made it easy to miss this symptom, despite our careful observation of these ambulant patients. Apart from the three cases discussed, another twenty patients were treated with Penidural, and two of these also showed skin hypersensitivity.

Of the remaining 32 patients (without erythema 
annulare), eight had slight to very slight cardiac abnormalities.

We are indebted to Dr. W. P. de Groot who carried out the skin biopsy and who gave permission to publish the photomicrograph.

\section{REFERENCES}

Ablard, G., and Larcan, A. (1956a). Rhumatologie, 8, 108. (1956b). Presse méd., 64, 1970.

Abt, A. F. (1935). Amer. J. med. Sci., 190, 824.

Barlow, T. (1883). Brit. med. J., 2, 509.

Bland, E. F. (1960). New Engl. med. J., 262, 597.

Burke, J. B. (1955). Arch. Dis. Childh., 30, 359.

Carole, W. L. L., and Krieken, J. A. van (1935). Acta paediat. (Uppsala), 17, 372.

Coburn, A. F. (1931). "The Factor of Infection in the Rheumatic State”, p. 226. Williams and Wilkins, Baltimore.

Gadrat, J. (1938). Ann. Derm. Syph., 8e sér., 9, 1045.

Irvine-Jones, E. I. M. (1928). Arch. intern. Med., 42, 784.

Lehndorff, H. (1930). Wien. med. Wschr., 80, 1449.

- and Leiner, C. (1922). Z. Kinderheilk., 32, 46.

Pellé, A., and Massot, H. (1937). Bull. Soc. méd. Hôp. Paris, p. 1250.

Perry, C. B. (1937). Arch. Dis. Childh., 12, 233.

Rayer, P. F. O. (1826-27). "Traité théorique et pratique des maladies de la peau", 2 vols. Baillière, Paris. (English translation, 1835.)

Slater, J. D. H., and Rosenbaum, S. (1959). Ann. rheum. Dis., 18, 285.

Swift, H. F., Wilson, M. G., and Todd, E. W. (1929). Amer. J. Dis. Child., 37, 98.
Traub, E. (1937). Z. Kinderheilk., 58, 769.

Wallgren, A. (1935). Acta paediat. (Uppsala), 17, 447.

Winkler, W. (1947). Ann. paediat. (Basel), 168, 303.

\section{Erythème annulaire chez des adultes atteints de rhumatisme aigu}

\section{RÉSUMÉ}

Dans un dispensaire rhumatologique on trouva trois cas d'érythème annulaire parmi 35 adultes atteints de rhumatisme aigu.

En raison de l'aspect équivoque de l'érythème annulaire on peut facilement manquer se symptôme, malgré l'observation soigneuse de ces malades ambulants. A part de ces trois cas discutés, vingt autres malades furent traités au "Penidural" et deux d'entre eux accusèrent une hypersensibilité cutanée.

Parmi les 32 malades restants (sans érythème annulaire) huit d'entre eux manifestèrent des anomalies cardiaques légères ou très légères.

\section{Eritema anular en adultos con reumatismo agudo}

\section{SUMARIO}

En una clínica reumatológica para enfermos externos se encontraron tres casos de eritema anular entre 35 adultos enfermos con reumatismo agudo.

A causa del aspecto equívoco del eritema anular, ese síntoma puede fácilmente pasar desapercibido, a pesar de la observación cuidadosa de estos enfermos ambulantes. Sin contar los tres casos discutidos, veinte otros enfermos fueron tratados con "Penidural" y dos de ellos acusaron una hipersensibilidad cutánea.

Entre los demás 32 enfermos (sin eritema anular) ocho casos manifestaron anomalías cardiacas ligeras o muy ligeras. 